\title{
Jurassic red nodular limestone from NE Slovakia used as the L'ubovňa "marble" during the Renaissance in Slovakia and Poland
}

\author{
Daniel PIVKO ${ }^{1, *}$ \\ 1 Comenius University, Faculty of Natural Sciences, Department of Geology and Paleontology, Ilkovičova 6, \\ 84215 Bratislava, Slovakia
}

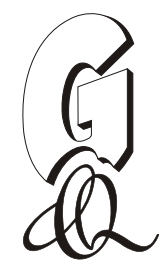

Pivko, D., 2017. Jurassic red nodular limestone from NE Slovakia used as the L'ubovňa "marble" during the Renaissance in Slovakia and Poland. Geological Quarterly, 61 (1): 53-61, doi: 10.7306/gq.1303

The L'ubovňa "marble" is red nodular limestone of Oxfordian to Tithonian age, which used to be extracted in several quarries near the town of Stará L'ubovňa in NE Slovakia. It replaced the Hungarian Gerecse "marble" which was extensively used in the Kingdom of Hungary and surrounding countries from the end of the 12th to the first third of the 16th century when its use was interrupted by the Turkish occupation of the area. The L'ubovňa "marble" was used as a substitution especially for Renaissance tombstones in today's Slovakia and Poland and it was found also in Hungary. It reached the top of its popularity between the mid-16th and mid-17th century. To a smaller extent it was still used in the surrounding territories during the other styles in the 18th and 19th centuries. The "marble" production was probably affected by the political situation and wars. It is possible to distinguish the L'ubovňa "marble" from the Gerecse "marble" and the Adnet "marble" from Austria macroscopically on the basis of its distinct cleavage, and microscopically on the basis of microfacies with Saccocoma, Globuligerina and calcareous dinoflagellates. According to the stable isotopes of ${ }^{18} \mathrm{O}$ and ${ }^{13} \mathrm{C}$, it is approximately similar to the Adnet "marble".

Key words: L’ubovňa “marble”, nodular limestone, Stará L'ubovňa, tombstone, Slovakia, Poland.

\section{INTRODUCTION}

Red stones have been popular since the antiquity, especially the Egyptian Imperial Porphyry. In Central Europe, the ancient Romans probably knew the red Gerecse and Adnet "marble" (Kieslinger, 1964; Hála, 1995 in Pintér et al., 2004). Since the end of the 12th century, red marbles, such as Gerecse "marble" in Esztergom (Varga and Lővei, 1990-1992) or Adnet "marble" in Salzburg (Kieslinger, 1964), became popular as a material for the decoration of churches and palaces. From the neighbouring countries, Moneasa (Menyháza) "marble" from Romania, Velykyi Kamenets' "marble" (Rosso Karpazi) from Ukraine, Slivenec "marble" from Bohemia and Italian Rosso Verona "marble" can be mentioned. From the period of international gothic (from the late 14th century) and then mainly during the Renaissance, red marble was used for exclusive tombstones. In Slovakia and Poland (Wardzyński, 2015), similar marble from NE Slovakia known as L'ubovňa "marble" was used instead of the firstly mentioned Gerecse and Adnet "marble". This marble from Stará L'ubovňa is presented in some papers (Nemčok et al., 1990; Murcko, 1995; Havlice, 1995; Pivko, 2010, 2012) and especially in articles of Wardzyński (2009, 2015). Yet, no comprehensive work about geology, extraction

\footnotetext{
*E-mail: pivko@fns.uniba.sk
}

Received: August 12, 2015; accepted: March 14, 2016; first published online: July 14, 2016 and usage of L'ubovňa "marble" has been carried out. This paper gives a synthesis of data on L'ubovňa "marble", which is based on the study of red limestone geology from several quarries and on the study of about hundred stone artefacts from the territory of present Slovakia, almost exclusively tombstones carved from red limestones. Valuable knowledge, ca. 50 artefacts, was obtained from the works of Wardzyński $(2009,2015)$. The dating of tombstones and other artefacts was based on either the inscriptions carved on tombstones or other works and sources (Števík, 2006, 2012; Wardzyński, 2009, 2015; Kresánek, 2009; Ludiková, 2010; Čovan, 2012, 2013, 2014; apsida, chramsvjakuba, hradlietava, hradlubovna, fara-kezmarok, obnova, rkcpoprad, kezmarok, spiskastaraves).

\section{PRESENT KNOWLEDGE OF L'UBOVŇA "MARBLE"}

The studied "marble" is connected with Stará L'ubovňa, a town in Spiš (Spisz in Polish, Zips in German) - a region in NE Slovakia close to the Polish border (Fig. 1). The earliest written evidence mentioning the town comes from the year 1292. Sometime after this year a castle was built near the town to protect the border of the Kingdom of Hungary and the nearby crossing of trade routes. When the castle was built, the importance of the settlement under the castle increased (Števík, 2012). In 1412, thirteen Spiš towns including Stará L'ubovňa were pawned to Poland by the Hungarian king Sigismund. The pawned territories remained politically part of the Kingdom of 


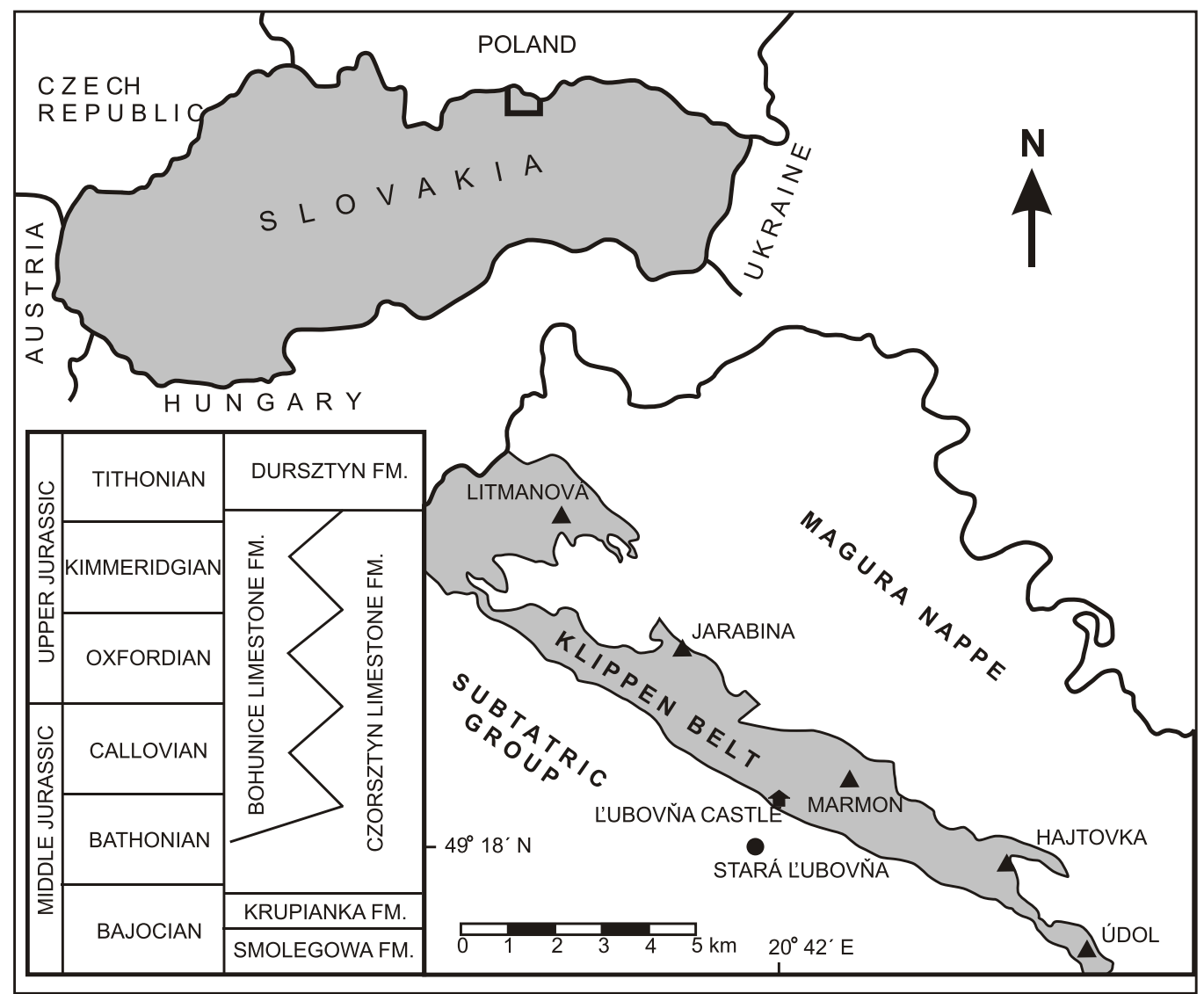

Fig. 1. The quarry area and stratigraphic scheme (not to scale) of L'ubovňa "marble" in the Pieniny Klippen Belt

Geological map modified according to map server

Hungary, but economically and administratively belonged to Poland under the name "Starostwo spiskie". The territory was administered from the L'ubovňa castle and became part of the Kingdom of Hungary again in 1770 (1769?). The interest of both, the Polish and the Hungarian crowns, created favourable conditions for their economic development and the towns had obtained various privileges and tax reliefs. The towns also participated in international trade and the Spiš markets were attended by Russian, Polish, Turkish, Dutch and German merchants with their products (Lengová, 2012).

The history of L'ubovňa "marble" extraction is connected with the occupation of the southern part of the Kingdom of Hungary by the Ottomans when Gerecse "marble" became no longer available. The L'ubovňa "marble" became the new substitution. It is Upper Jurassic brown-red nodular limestone and it was also known as lubowelski or lubowlański "marmur" in Poland (Wardzyński, 2009, 2015) and lubovniansky "mramor" in Slovakia. The discovery of the marble source and the establishment of new quarries can be most likely attributed to Piotr Kmita the Younger, Spiš starosta, who had obtained a royal privilege (1524-1542) which allowed him to perform the prospection and extraction of minerals and metal ores in the area (Kowalska, 1967-1968). The tombstone of Piotr Kmita in Kraków, dated to 1558 , is also carved from this marble (Wardzyński, 2009). The abandoned quarry can be found only a few kilometres $E$ from Stará L'ubovňa between the villages Podsádok and Matysová, near the Marmon settlement (Fig. 1).
According to Wardzyński (2009, 2015), L'ubovňa "marble" can be found in some Renaissance masterpieces in Slovakia and in the middle and south of the Małopolska territory. Domestic, north-Italian and south-Swiss artisans and masons used this marble and a similar type with bleachings. Especially tombstones and, to a smaller extent, portals and other architectonic details can be found in Małopolska, Wielkopolska, Mazowsze and the Prusy territory of the Kingdom of Poland. The period of the most extensive use of this marble lasted from the mid-16th to mid-17th century.

It is not clear whether L'ubovňa "marble" was extracted later. The second military survey map (1806-1869) indicates that quarries might have existed near the Marmon and Údol (Ujak) settlements (Figs. 2 and 3; mapire.eu). Other references indicate that the red nodular limestone from Marmon was quarried and processed by cutting, grinding and polishing to produce formatted "Marmon marble" for tombstones and tablets which were exported to Hungary and Poland (Murcko, 1995; www.chmelnica.sk). According to the list of quarries in the Kingdom of Hungary, there was extraction of red Jurassic limestone in Jarabina for building and in Stará L'ubovňa for burning lime and occasionally for small tombstones and border stones (Schafarzik, 1909). The quarry near the Marmon settlement was founded by Count Zamojski in the late 19th century and belonged to him until 1945. Extracted limestone was mainly exported into Kraków, where facing plates were produced (Lang, 1958; Hrušovský et al., 1983). 

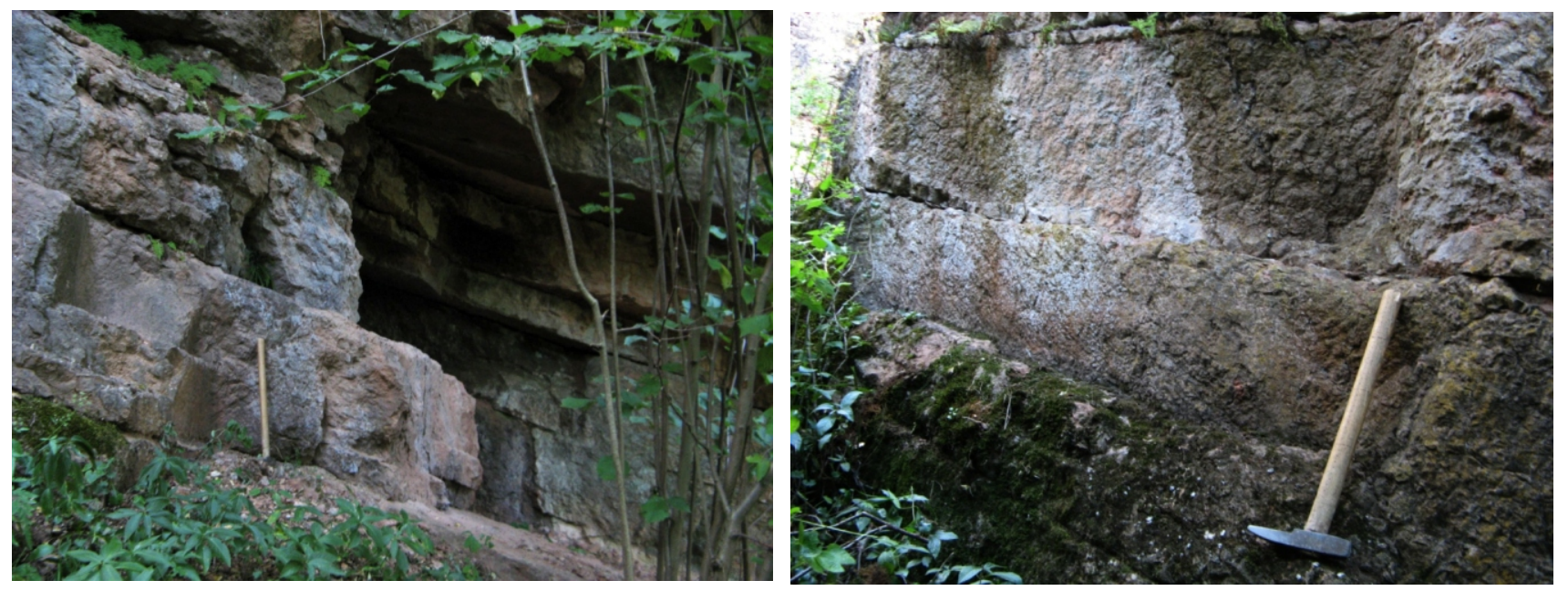

Fig. 2. The historical part of the Marmon Quarry with block extraction and tool marks on the surface

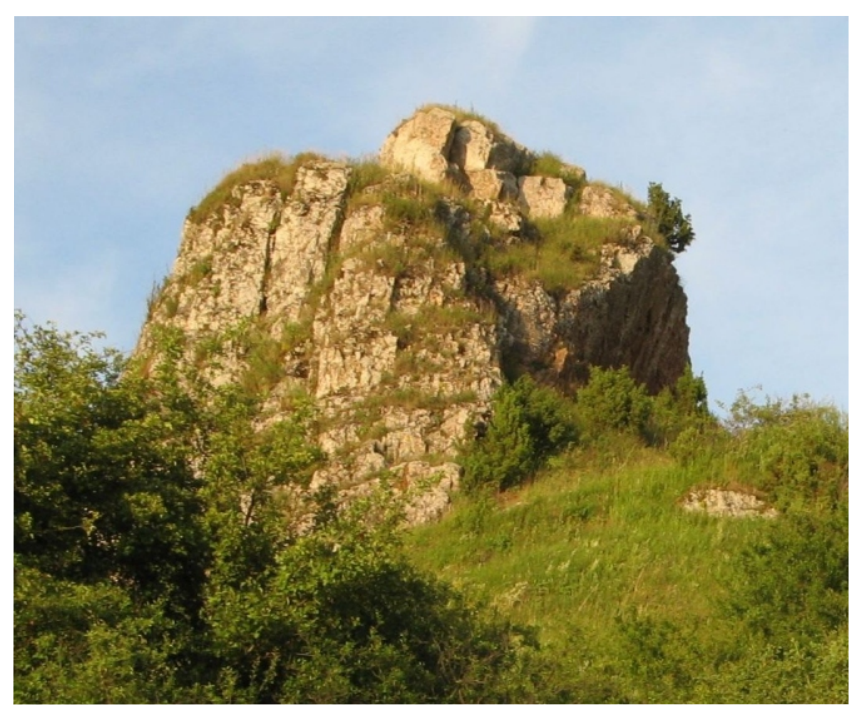

Fig. 3. Traces of the historical extraction in the Údol klippe

In the 1950s, a survey of Marmon deposit was carried out (Lang, 1958) which made it apparent that the quarry was not suitable for ornamental stone extraction. The deposit was again and in more detail examined from 1979 to 1983 (Hrušovský et al., 1983). The conclusion of the research report was that the volume of extractable block was very small and the limestone was suitable only for conglomerate tiles. Tentative extraction was performed by the company which owned the quarry at the end of the 20th century. Some marble tiles that are probably from Marmon and can be found in some eastern Slovakia churches might have originated from this extraction.

The thickness of the Marmon deposit varies from 20 to $35 \mathrm{~m}$, and the thickness of beds varies from 10 to $60 \mathrm{~cm}$. The dip direction of beds was $25^{\circ}$ ENE. Water absorption of limestone was 0.3 to $0.8 \%$, compressive strength 55 to $125 \mathrm{MPa}$ (Lang, 1958; Hrušovský et al., 1983).

Nodular limestones exhibit a conspicuous fabric characterized by centimetre- and decimetre-sized, often "rounded" nodules floating within a usually micritic matrix. The overall appearance sometimes resembles a conglomerate. The origin of the nodular fabric has been explained by diagenetic, sedimentary and tectonic processes. Diagenetic processes include solution processes as well as cementation and nodule growth within the sediment. Sedimentary models underline the role of transport and redeposition. Tectonic explanations favour the formation of nodular fabrics by shear processes affecting limestone-marl/clay alternations (Flügel, 2010).

\section{PETROGRAPHIC ANALYSIS}

\section{MACROSCOPICAL DESCRIPTION}

The examined artefacts are composed of red nodular to massive limestones. Similar limestones, as it was mentioned in the history of extraction, can be found in some quarries near Stará L'ubovňa. Dozens of tombstones and also beds in quarries were examined. They are composed of Upper Jurassic red nodular limestones with evident or less evident nodules up to several centimetres in size (Fig. 4), usually emphasized with darker stylolites. Stylolites or better cleavage are developed at high angles to the pre-existing bedding-parallel foliation. The cleavage bypasses nodules, creating lenticular structure (Fig. 5). The cleavage strikes (according to Plašienka, 2012) are from WNW-ESE to WSW-ENE with maximum approximately W-E.

Red "marble" is a simplified designation for this type of polishable rock. The typical colour varies from brown-red to brown-orange or brown-pink. After weathering, the surface is covered by pinkish, beige-grey to grey colour. The colours of the rocks were compared with the colours defined in the Geological Rock-Color Chart (2009). Limestone colour was determined for nodules as moderate reddish orange (10R 6/2) to pale reddish brown (10R 5/4) and for the matrix between nodules as moderate reddish brown $(10 \mathrm{R} 4 / 6)$ to dark reddish brown (10R 3/4). Limestones were often cut by white calcite veins. In some types there were bleaching zones of beige-grey to greenish colour, a few centimetres thick (Fig. 6). Some nodules were compressed ammonites.

\section{CHEMICAL AND MINERALOGICAL ANALYSIS}

According to the geological exploration of the historical Marmon Quarry deposit, the chemical composition of four sam- 


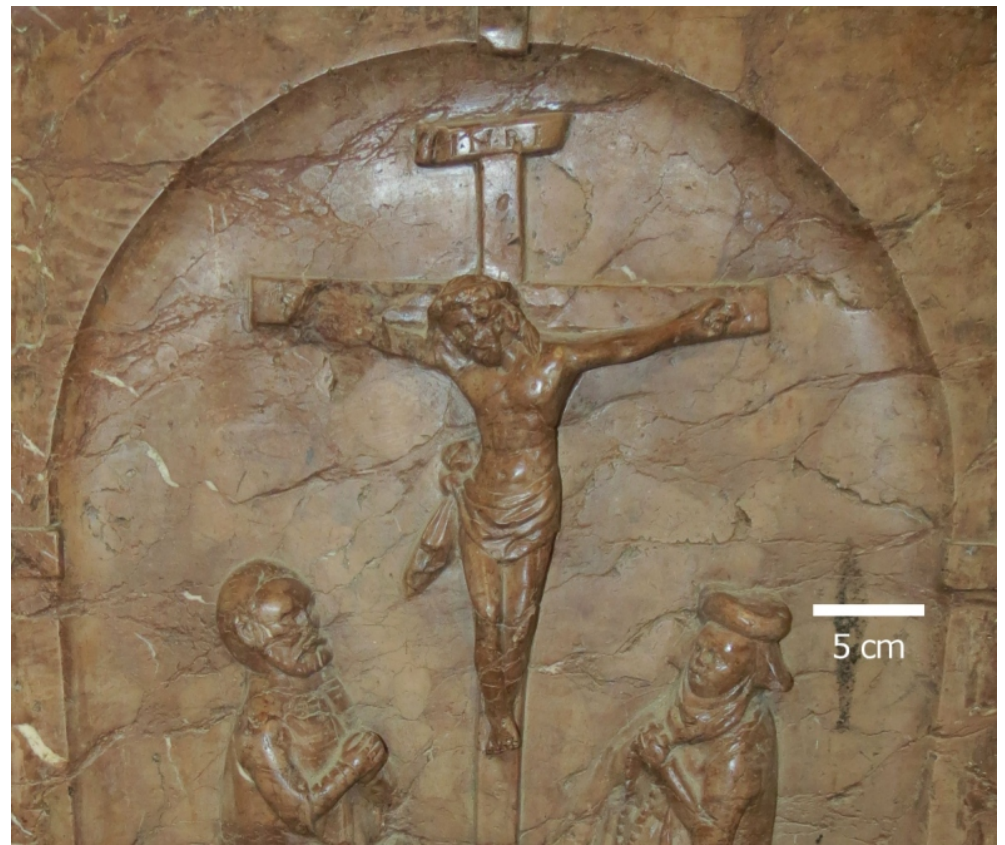

Fig. 4. The polished tombstone from 1622 carved from redish nodular limestone - L'ubovňa "marble” (Stará L'ubovňa Museum in the castle) the cultural heritage. Nevertheless, it was possible to acquire samples of weathered tombstones from Levoča and Stará L'ubovňa. The samples were compared with 10 samples from the Marmon and Údol Quarry and thin section analysis in Hrušovský et al. (1983). According to the microscopic study, the samples were packstones, sometimes wackstones (Dunham, 1962) and intrabiomicrites (Folk, 1962).

The limestone samples contained a micritic or sometimes microsparitic matrix, in which the concentration of fossils in intraclasts, which are nodules, varied from packed to scattered. Most of the samples contained Saccocoma microfacies (Fig. 7) and its variation as "filament" - Saccocoma microfacies, Saccocoma-Globochaete microfacies. In addition to abundant Saccocoma and variable contents of Globochaete and Bositra, the samples contained also radiolarians, ostracods, crinoids, foraminifers such as Globuligerina, Nodosaria, Involutina, Spirilina, recrystallised bivalves, brachiopods, aptychi and calcareous dinoflagellates Colomisphaera minutissima, C. carpathica, C. lapidosa, C. fibrata, C. nagyi, C. pulla, Carpistomiosphaera borzai, Ca. tithonica, Cadosinaparvula and Stomiosphaera moluccana. According to microfacies and dinoflagellates (Reháková, 2000; Reháková et al., 2011), the rocks of the samples are of Oxfordian, Kimmeridgian and Tithonian ages. Abundant compressed aggregates of iron (III) oxide-hydroxide, clay minerples is as follows: $\mathrm{CaO} 49.4-52.4 \%, \mathrm{SiO}_{2} 2.7-5.9 \%, \mathrm{Al}_{2} \mathrm{O}_{3}$ $0.8-1.8 \%, \mathrm{Fe}_{2} \mathrm{O}_{3} 0.9-1.4 \%, \mathrm{MgO} 0.3-1.0 \%, \mathrm{~K}_{2} \mathrm{O} 0.2-0.4 \%$, $\mathrm{Na}_{2} \mathrm{O} 0.2 \%, \mathrm{P}_{2} \mathrm{O}_{5} \quad 0.1-0.2 \%, \mathrm{SO}_{3} \quad 0.1 \%$ and $\mathrm{MnO} 0.1 \%$ (Hrušovský et al., 1983). The analysis and observation of thin-sections show that the limestones are composed mainly of calcite, a small amount of clay minerals, ferrous oxide and hydroxide, quartz, chalcedony, apatite, muscovite and Mn oxides. It can be assumed magnesium is bound in the form of Mg-calcite, e.g. in echinoderms.

\section{MICROSCOPICAL ANALYSIS}

Obtaining a reasonably large sample from the historic stone artefacts for analysis is quite difficult due to the preservation of als and \pm quartz were found between the nodules. Occasionally, calcite veins were present.

\section{ISOTOPE ANALYSIS}

Ornamental stones in general are often compared on the basis of oxygen and carbon stable isotopes. The advantage of this method is the necessity of only a small sample of the rock about $1 \mathrm{mg}$. Nine whole rock samples from four quarries and nine whole-rock samples from tombstones were tested. The samples were processed in the laboratory of the Dionýz Štúr State Geological Institute in Bratislava. The results of $\delta^{18} \mathrm{O}_{V-P D B}$ and $\delta^{13}$ CV-PDB analysis are summarized in Figure 8.
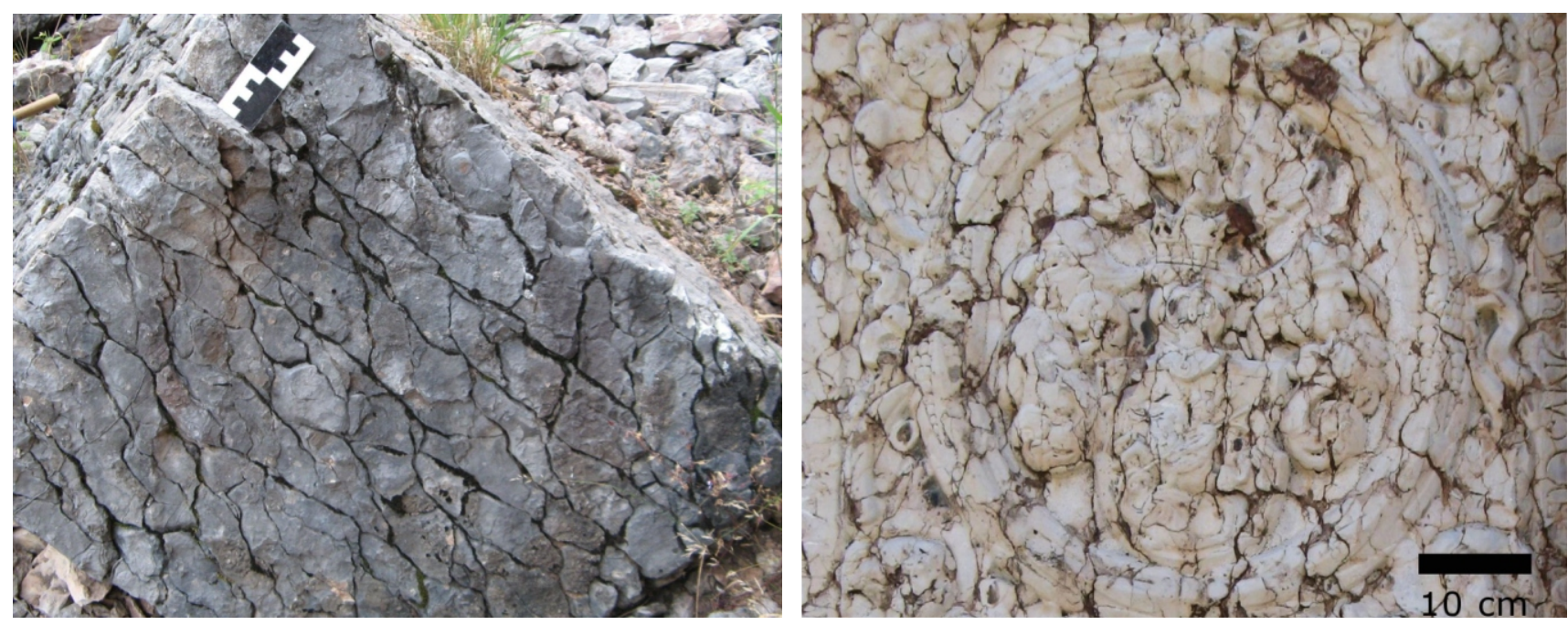

Fig. 5. Cleavage in a stone block from the Marmon Quarry and in the tombstone from the 17th century (Sabinov parish church) 

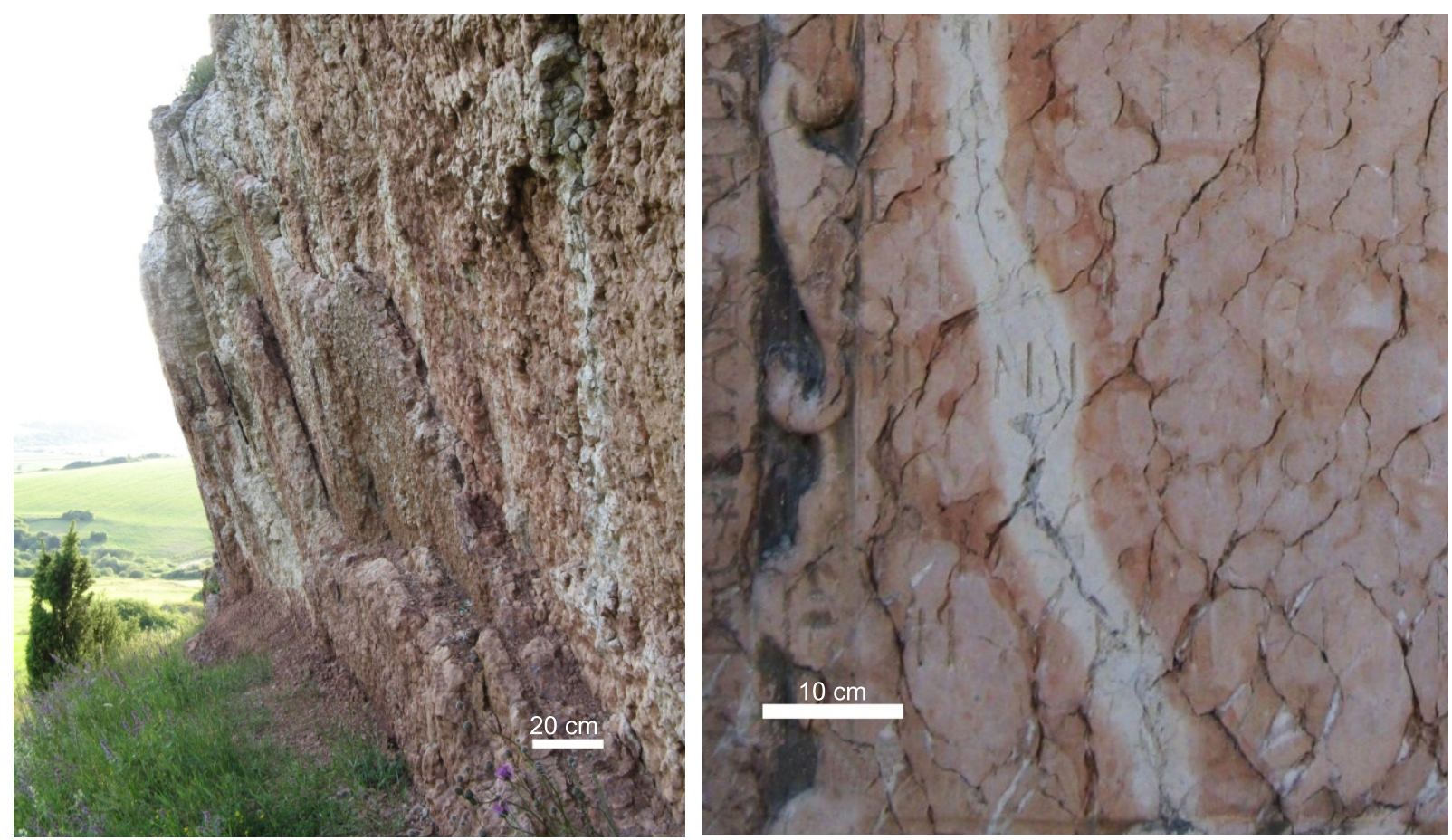

Fig. 6. Bleaching zones in L'ubovňa "marble" in the extracted quarry face from the Údol klippe, and the bleaching on a tombstone from 1636 with some ammonite nodules (Sabinov parish church)
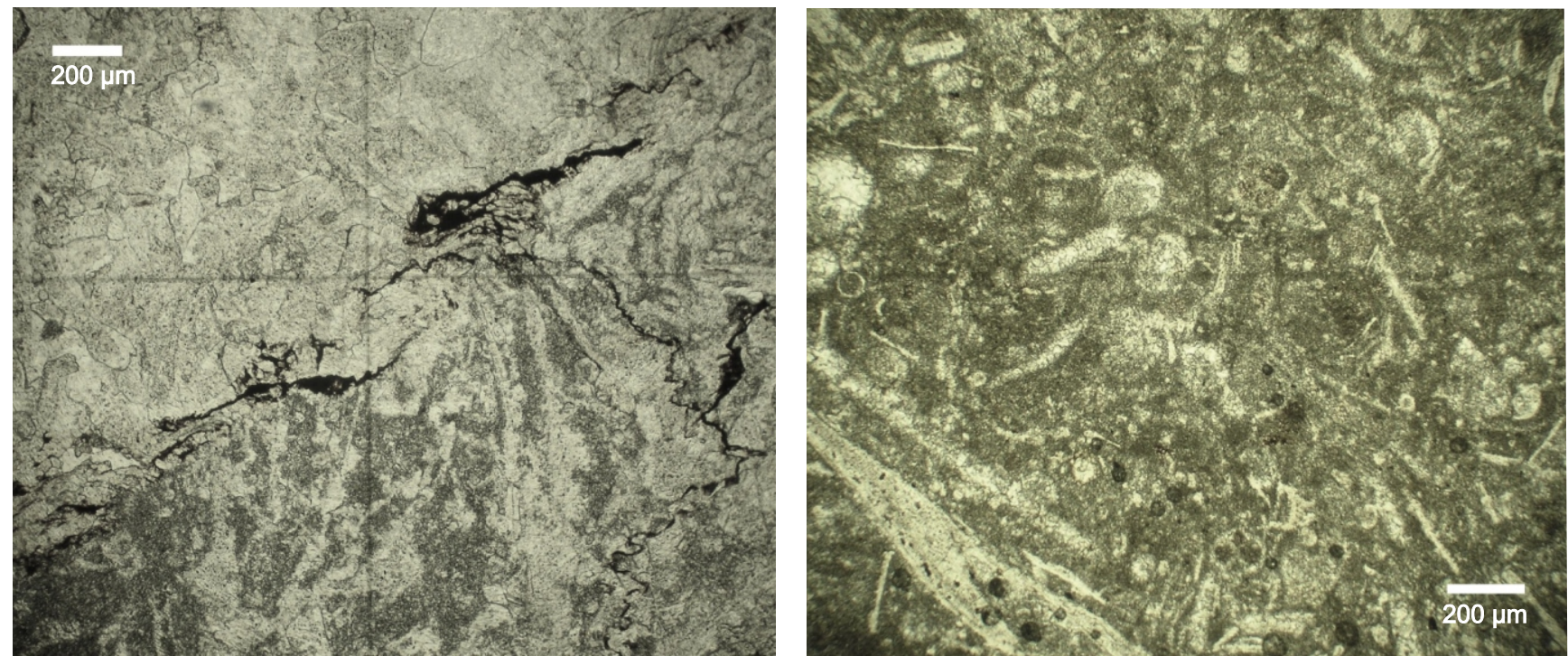

Fig. 7. The Saccocoma microfacies with the wackstone and grainstone (red nodular limestone of Kimmeridgian age in the Marmon Quarry) and the "filament" - Saccocoma microfacies (red nodular limestone of Late Oxfordian to Early Kimmeridgian age from the tombstone in the Levoča church) (plane-polarized light)

\section{INTERPRETATION OF THE RESULTS}

Red nodular to massive limestones from Marmon, Údol, Hajtovka, Litmanová and Jarabiná quarried klippes (Figs. 1-3) of the Czorsztyn and Bohunice Limestone Formation of Late Bajocian to Early Tithonian age of the Czorsztyn Unit of the Pieniny Klippen Belt (Aubrecht and Sýkora, 2004; Schlögl et al., 2009; Aubrecht and Jamrichová, 2009). According to Plašienka et al. (2012), the localities belong to the Šariš and Subpieniny units of the Pieniny Klippen Belt.

Based on the spectral analysis in Hrušovský et al. (1983), it can be concluded that the more calcite-clay mineral matrix and cement the sample has, the greater amount of $\mathrm{Fe}, \mathrm{Mn}, \mathrm{Cu}, \mathrm{Cr}$, $\mathrm{P}, \mathrm{Ni}$ is present.

According to microfacies and calcareous dinoflagellates, the analysed samples from quarries and tombstones are of Oxfordian to Early Tithonian age, which corresponds to the 


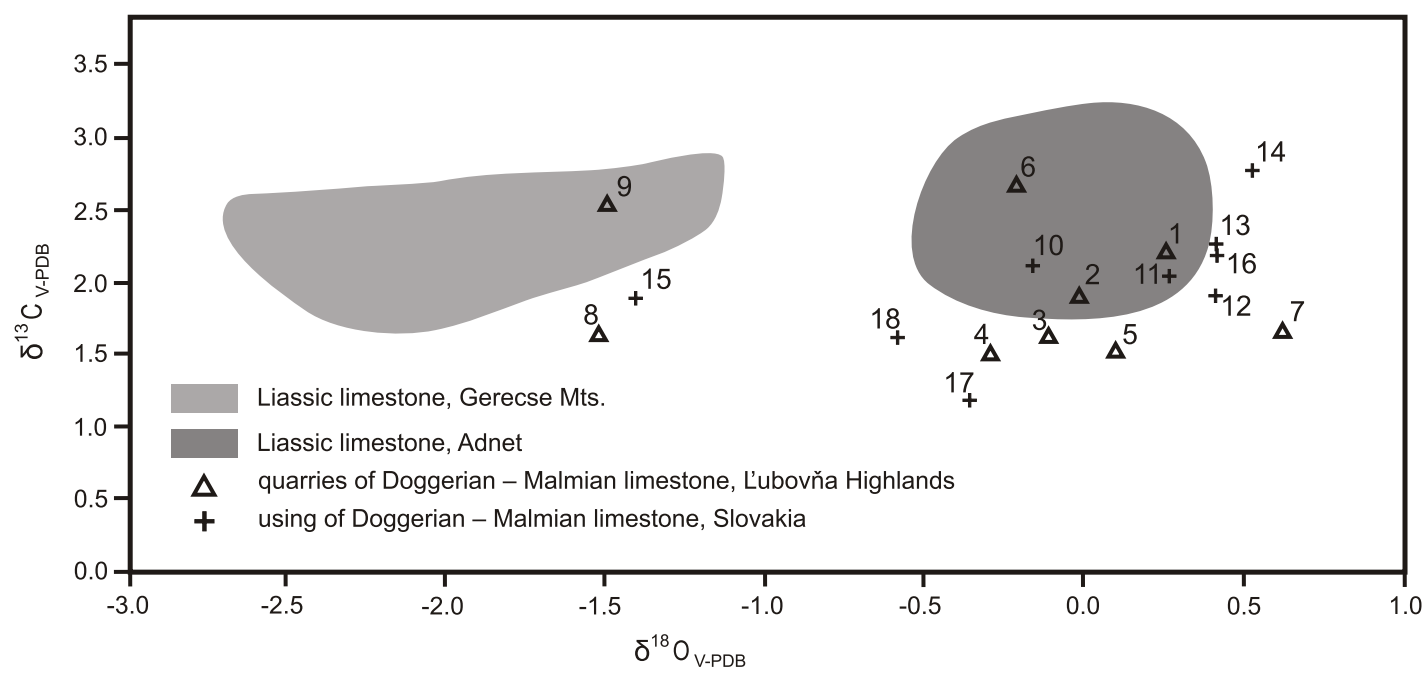

Fig. 8. The plot of $\delta^{18}$ ov-PDB and $\delta^{13}{ }_{\text {CV-PDB }}$ values

The Liassic Gerecse limestone field is based on 17 points (Pintér et al., 2004) and the Liassic Adnet is limestone based on 28 points (Böhm et al., 1999; Pintér et al., 2004); quarries: 1-5 - Marmon; 6, 7 - Údol; 8 - Hajtovka; 9 Litmanová, and tombstones: 10-12 - Stará L'ubovňa from 1584, 1605 and 1672; 13,14 - Sabinov from 1558 and 1636; 15, 16 - Levoča from 1558 and 1590; 17, 18 - Košice from the Renaissance

Czorsztyn and Bohunice Limestone Formation. Extracted blocks from quarries come only from the upper part of lithological section.

The tombstones and other artefacts can be assigned into the Czorsztyn and Bohunice Limestone Formation on the basis of the age mentioned above, macroscopic features, and stable isotopes. At a first glance the red nodular limestones of the tombstones and beds inspected in quarries are similar to the Gerecse and Adnet red nodular limestones. Abundant calcite veins resemble the Adnet red nodular limestones, while the bleaching areas slightly resemble the Adnet Rotschnöll type (Kieslinger, 1964). A typical characteristic of the L'ubovňa "marble" from the Czorsztyn and Bohunice Limestone Formation is the cleavage of lenticular shape.

Cleavage is an early-stage planar structure that is developed at high angles to the pre-existing bedding-parallel foliation. The cleavage of the L'ubovňa "marble" was formed during the late diagenetic stage in not fully lithified sediment, as revealed by analogous deformation mechanisms - pressure solution and concentration of insoluble clayey material along the new foliation surfaces. Under the very low-grade temperature conditions, the clay minerals transformations, such as smectite to illite, produced additional aqueous fluids necessary for pressure solution processes. Instead of vertical compaction and flattening resulting from the sedimentary load, it was the subhorizontally operating maximum tectonic stress axis. Sedimentary rock complexes suffered bedding-parallel shortening during this deformation stage (Plašienka, 2012).

The bleaching which was visible on some tombstones in Slovakia and Poland (Wardzyński, 2015) was also observed in the upper part of the Marmon Quarry limestone sequence and in the Údol Quarry (Fig. 6). The same characteristic is mentioned also in Lang (1958). Bleaching zones were probably caused by reducing fluids flowing through fissures.

Based on the $\mathrm{O}$ and $\mathrm{C}$ isotope analysis, most of the samples have similar values to the Adnet limestones (according to Böhm et al., 1999; Pintér et al., 2004), but the area of the L'ubovňa "marble" on the plot is larger. These are the samples from the Marmon Quarry and the Údol Quarry and tombstones from Stará L'ubovňa, Košice, Levoča and Sabinov. Only three samples - the samples from the Litmanová and Hajtovka quarries and one tombstone from Levoča - resemble the Gerecse limestone. It is possible that they belong to a different stratigraphic horizon than the other samples.

The best and unambiguous sign of the L'ubovňa "marble" is the combination of lenticular cleavage by passing nodules with tiny fissures at weathered surfaces and white calcite veins. Microscopically, there are microfacies typical for the Late Jurassic epoch. L'ubovňa "marble" has worse quality characteristics than Gerecse and Adnet "marbles", which is manifested mainly during the weathering. L'ubovňa "marble" gets disintegrated easier because of the cleavage surfaces enriched with clay minerals and limonite, and microfissures along them. Probably, the most suitable name for the red nodular limestone from the Stará L'ubovňa vicinity is L'ubovňa "marble", while the most quarries deposits are situated near Stará L'ubovňa and the most important Marmon Quarry is located in the Stará L'ubovňa municipality. Other names used were Spiš "marble" ("marmur spiski") mentioned by Wardzyński (2009) or Marmon "marble" ("marmonský mramor; Murcko, 1995).

Marmon is only one of the localities although the most famous. Marmon is the most commonly used name on the military survey maps from 1869-1887, 1952-1957 and 1957-1971 (mapire.eu). Worth mentioning are also the other names: Marmony used on the military survey map from 1788 (Mikulík, 2015), Marmont (special map 1:75,000 in geo.enviroportal.sk; Hrušovský et al., 1983) and Marmonn (military mapping in 1806-1869; mapire.eu). Marmon (Marmont), an unusual historical name in the Slovak territory, is derived from marble extraction. It is probably an abbreviation from Latin marmor, marmore (marble) and monte (mount), as the Latin language was widely used in the region during the Renaissance. Italians might have worked in this quarry too, as Italian stone masons and sculptors were known in Kraków (Wardzyński, 2009). Signs of the past exploitation such as steep parallel marks made by a pick are still visible in the Marmon Quarry (Fig. 2). 


\section{THE USAGE OF L'UBOVŇA "MARBLE"}

The origin of most of the tombstones and other artefacts was determined by macroscopic features. According to historical references, marble began to be quarried after the exploration activities of Piotr Kmita (1524-1542), and it reached its popularity between the mid-16th and mid-17th century. The temporal distribution is shown in Figure 9. The approximate age of tombstones can be also derived from the date carved on it, but certain caution must be taken into account as tombstones might have been finished after or even a few years prior to the death of the buried person.

The spatial distribution of the studied products is presented in Figure 10. The red marble plastic products were exported especially to today's eastern Slovakia and the Małopolska region in Poland. Some of the products can be found also in the central and western part of Slovakia. In Poland, the "L'ubovňa marble" products can be seen in the territories of Wielkopolska, Mazowsze, Prusy and Śląsk (Wardzyński, 2009). One tombstone was also identified in NE Hungary.

The L'ubovňa "marble" became widely used in the 1550 s and its popularity continued mainly until the 1650 s predominantly in eastern Slovakia and to a smaller extent in other areas, too. After this period until the 19th century, it was quarried only rarely, and was used mainly in the surrounding towns such as Stará L'ubovňa and Kežmarok. Most products can been found in Stará L'ubovňa (25), Levoča (15), Košice (11), Kežmarok (8) and Bardejov (7). Havlice (1995) assumed that the tombstones in Košice dated to 1486, 1512 and 1516 were made of Marmon "marble", but they have characteristics of Gerecse "marble".

The "marble" was also exported to the Kingdom of Poland between the mid-16th to mid-17th century. However, between the 1620 s and 1640 s, it was only exported to Małopolska. Mostly tombstones, but also memorial tables, portals and other architectural elements were carved from L'ubovňa "marble" by domestic, Polish, Italian and Swiss stone masons and sculptors (Wardzyński, 2009). In Slovakia, baptismal fonts were also found.

The quantity of marble production was probably influenced by political events, too. The decline in production during the 1570 s and 1580 s might have been caused by the Ottoman raids to Spiš, for example in 1570 (Horváth and Kopčan,
1971), and the consequent occupation of Spiš by the Austrian army between 1586 and 1589 during the War of the Polish Succession also known as the Habsburg-Polish war (Chalupecký and Smetana, 1987). During the second decade of the 17th century, between the rebellions of Bočkaj and Betlén in the area of present Slovakia, the production reached its peak. The decline of export to Poland in the mid-16th century is probably related to the onset of the Thirty Years' War. The end of the usage of L'ubovňa "marble" in Poland was probably caused by the Swedish Deluge between 1655 and 1660 or by the changes in fashion (Wardzyński, 2009) and the orientation to other materials.

\section{SUMMARY}

In the Kingdom of Hungary, the Gerecse red "marble" has been used since the late 12th century. It was exported to the neighbouring countries, e.g. to Poland from last quarter of the 14th century, while in the western part of Slovakia, the Adnet "marble" of Salzburg was progressively imported via the Danube from 1560s. When the southern part of the Kingdom of Hungary was occupied by the Ottomans in the first half of the 16th century, a new source of red marble was searched for

The new source of "red marble" was discovered in today's NE Slovakia in the Spiš region. The most famous marble quarry called Marmon was located near the Stará L'ubovňa castle. The extraction of L'ubovňa "marble" probably took place also in the Údol, Hajtovka, Litmanová and Jarabiná quarries. The "marble" is a brown-red to brown-pink nodular limestone of Oxfordian to Tithonian age, belonging to the Czorstyn and Bohunice Limestone Formation (Ammonitico Rosso) of the Pieniny Klippen Belt. It differs from Adnet and Gerecse "marbles" by age and Saccocoma (Globochaete) microfacies. Common calcite veins, occasional bleachings and relation between the oxygen and carbon stable isotopes make the L'ubovňa "marble" similar to Adnet "marble". The unique feature of L'ubovňa "marble" is the cleavage that bypasses nodules and creates lenticular structure. However, this characteristic is also a disadvantage of the "marble" as it makes it more vulnerable to weathering.

Between the 1550s and 1650s, L'ubovňa "marble" became used in Slovakia, significantly in the eastern part. Later, until the

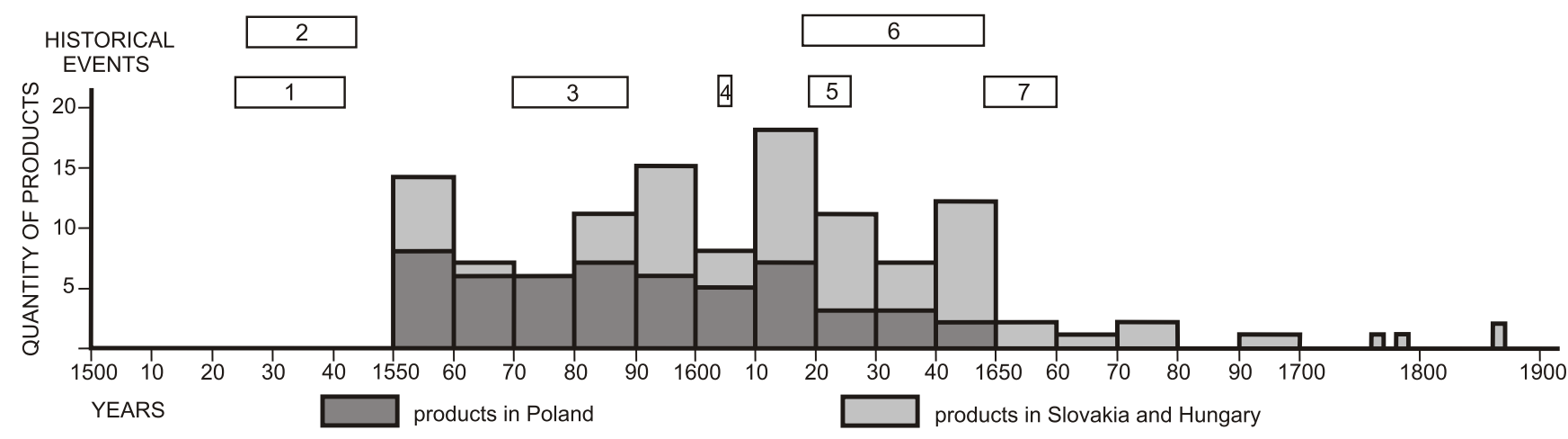

Fig. 9. The temporal distribution of the L'ubovňa "marble" products

1 - the royal privilege for Piotr Kmita to perform the prospection and extraction of minerals, 2 - progressive occupation of southern Hungary by the Ottomans, 3 - the Ottoman raids to Spiš and the occupation of Spiš by the Austrian army, 4 - Bočkaj's rebellion, 5 - Betlén's rebellion, 6 - Thirty Years' War, and 7- the Swedish Deluge 


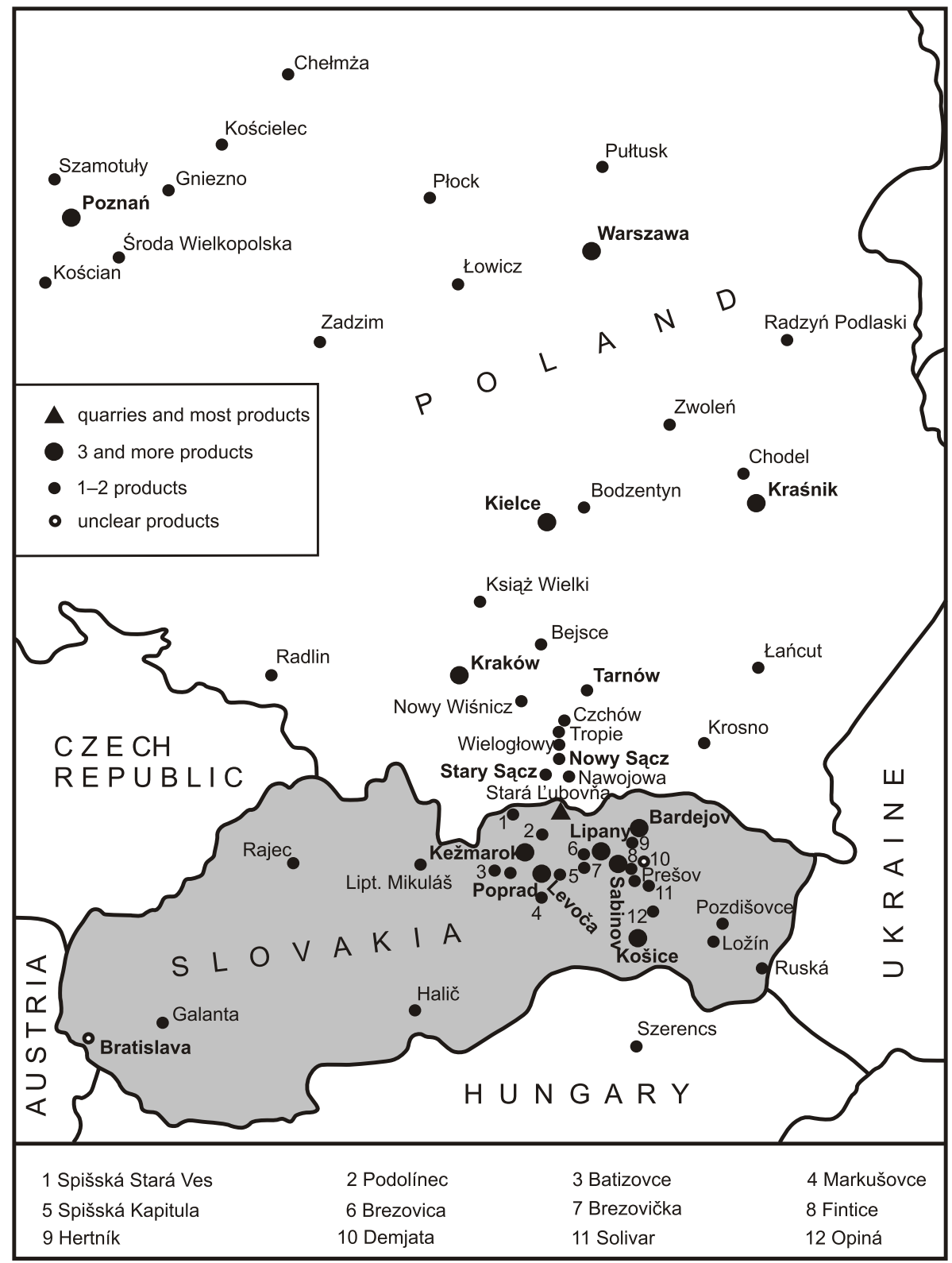

Fig. 10. The spatial distribution of the L'ubovňa "marble" products according to Wardzyński (2009), supplemented

19th century, it was quarried only for the nearby areas. Most artefacts can be found in Stará L'ubovňa, Levoča, Košice, Kežmarok and Bardejov. The "marble" was exported to the Kingdom of Poland from the mid-16th to mid-17th century. Not only tombstones, but also memorial tables, portals and other architectural elements were carved of L'ubovňa "marble". Political events probably influenced the quantity of marble production. The decline in production during the 1570s and 1580s might have been caused by war events in the Spiš area. The peak of the "marble" production was reached in the 1720s between the rebellions of Bočkaj and Betlén. In Poland, L'ubovňa "marble" stopped being used probably because of the Swedish Deluge (1655-1660) or due to the orientation to other stone types.

Acknowledgements. Many thanks to Grant APVV-14-0118 for financial support. Many thanks are due to two anonymous journal reviewers, to Prof. D. Reháková, Dr. J. Schlögl, Prof. D. Plašienka, Prof. R. Aubrecht for valuable expert advice, MSc J. Kubeš and Dr. M. Kubeš for English editing, Mrs. $V$. Némethová for drafting figures, my wife Marta, and above all to God. 


\section{REFERENCES}

Aubrecht, R., Jamrichová, M., 2009. Štepnická skala Klippe unique type of the Czorsztyn Succession (Pieniny Klippen Belt, Western Carpathians). Acta Geologica Slovaca, 1: 114-158.

Aubrecht, R., Sýkora, M., 2004. Jurassic-Cretaceous evolution of the Czorsztyn Unit (Pieniny Klippen Belt, Western Carpathians): new aspects. Geolines, 17: 15-16.

Böhm, F., Ebli, O., Krystyn, L., Lobitzer, H., Rakús, M., Siblik, M., 1999. Fauna, stratigraphy and depositional environment of the Hettangian-Sinemurian (Early Jurassic) of Adnet (Salzburg, Austria). Abhandlungen des Geologischen Bundesanstalt, 56: 143-271.

Chalupecký, I., Smetana, M., 1987. Hrad L'ubovňa. Osveta, Martin.

Čovan, M., 2012. Sepulchral monuments of important Šariš families. Source to the genealogical research of nobility (in Slovak). In: Magnate families in our history 1526-1948 (ed. F. Federmayer): 292-311. Almanach Slovenskej Genealogicko-Heraldickej Spoločnosti.

Čovan, M., 2013. Sepulchral monuments in Šariš during the Medieval and early modern periods (in Slovak). Epigraphica et Sepulcralia, Praha, 4: 73-116.

Čovan, M., 2014. Renaissance sepulchral monuments in Záborské (in Slovak). Pamiatky a Múzeá, 63: 35-38.

Dunham, R.J., 1962. Classification of carbonate rocks according to depositional texture. AAPG Memoir, 1: 108-121.

Flügel, E., 2010. Microfacies of Carbonate Rocks: Analysis, Interpretation and Application. Springer-Verlag, Berlin, New York.

Folk, R.L., 1962. Spectral subdivisions of limestone types. AAPG Memoir, 1: 62-85.

Geological Rock-color Chart with genuine Munsell color chips 2009, Munsell Color.

Havlice, I.,1995. Stone architectural elements and tombstones (in Slovak). In: Gothic art from Košice collections (ed. V. Glatz): 103-131. Katalóg Výstavy, Košice.

Horváth, P., Kopčan, V., 1971. Turks in Slovakia (in Slovak). SPN, Bratislava.

Hrušovský, S., Hudáček, J., Sohnová, S., Mrosko, J., 1983. The Final Report and Calculation of the Reserves of Stará L'ubovňa - VP Ornamental Stone (in Slovak). Manuscipt, Geologický Prieskum Spišská Nová Ves.

Kieslinger, A., 1964. Die nutzbaren Gesteine Salzburgs. Berglandbuch.

Kowalska, H., 1967-1968. Kmita Piotrz Wiśnicza h. Szreniawa (in Polish). In: Polski słownik biograficzny XIII. Wrocław-KrakówWarszawa-Gdańsk: 99

Kresánek, P., ed., 2009. Slovakia. Illustrated encyclopaedia of Monuments (in Slovak). Simplicissimus, Bratislava.

Lang, L., 1958. Research of Marble Deposit from 1957 Stará L'ubovňa (in Slovak). Manuscript, Geologický Průzkum, Brno.

Lengová, M., 2012. Trading activities in the Zips region (15th to 17 th century) (in Slovak). Človek a spoločnos, 15 www.saske.sk/cas/zoznam-rocnikov/2021/2/5975

Ludiková, Z., 2010. Statuary. Catalogue for the illustrated section (in Slovak). In: Renaissance (ed. I. Rusina): 271-283, 766-799. Slovart, Bratislava

Mikulík, D., 2015. Map of the L'ubovňa castle surroundings from 1788 (in Slovak). Hradná revue: www.hradlubovna.sk/hradna-revue

Murcko, M., 1995. Historical Lexicon of Communities of the Stará L'ubovňa District. 2nd part: N-V (in Slovak). Metodické Centrum Prešov.

Nemčok, J., Zakovič, M., Gašpariková, V., Ďurkovič, T., Snopková, P., Vrana, K., Hanzel, V., 1990. Explanatory notes to the geological map of Pieniny, Čergov, L'ubovña and Ondava highlands 1:50 000 (in Slovak). GÚDŠ, Bratislava.

Pintér, F., Szakmány, G., Demény, A., Tóth, M., 2004. The provenance of "red marble" monuments from the 12th-18th centuries in Hungary. European Journal of Mineralogy, 16: 619-629.
Pivko, D., 2009. The provenance of stone tabernacle and altartable from the St. Emmeram's Cathedral (Nitra City). Acta Geologica Slovaca, 1: 119-124

Pivko, D., 2010. Important rocks used as dressed stones in historical monuments of Slovakia (in Slovak). Mineralia Slovaca, 42: 241-248.

Pivko, D., 2012. Building and ornamental stone and their working in Middle Age Slovakia (in Slovak). Archaeologia Historica, 37: 609-628.

Plašienka, D., 2012. Early stages of structural evolution of the Carpathian Klippen Belt (Slovakian Pieniny sector). Mineralia Slovaca, 44: 1-16.

Reháková, D., 2000. The evolution and the distribution of the Late Jurassic and Early Cretaceous calcareous dinoflagellates recorded in the Western Carpathian pelagic carbonate facies. Mineralia Slovaca, 32: 79-88.

Reháková, D., Matyja, B.A., Wierzbowski, A., Schlögl, J., Krobicki, M., Barski, M., 2011. Stratigraphy and microfacies of the Jurassic and lowermost Cretaceous of the Veliky Kamenets section (Pieniny Klippen Belt, Carpathians, Western Ukraine). Volumina Jurassica, 9: 61-104.

Schafarzik, F., 1909. Detaillierte Mitteilungenüber die auf dem Gebiete des Ungarischen Reichesbefindlichen Steinbrücher. Publikationen der Königlich Ungarischen Geologischen Reichsanstalt.

Schlögl, J., Michalík, J., Plašienka, D., Aubrecht, R., Reháková, D., Tomášových, A., Bučová, J., Mikuš, V., Sýkora, M., Golej, M., 2009. Jurassic and Lower Cretaceous deposits of the Pieniny Klippen Belt and the Manín Unit in the Middle Váh Valley (Biele Karpaty and Strážovské vrchy Mts, Western Slovakia). Geologia, 35: 119-181.

Števík, M., 2006. The memorial tablets of Spiš starosta Lubomirský in the L'ubovňa and the Podolínec castles (in Slovak). In Almanach Muszyny. Rocznik pod Patronatem Towarzystwa Miłośników Ziemi Muszyńskiej: 123-129.

Števík, M., 2012. Seven Centuries of the L'ubovňa Castle (in Slovak). L'ubovnianske Múzeum, Stará L'ubovňa: 1-53.

Varga, L., Lővei, P., 1990-1992. Funerary art in medieval Hungary. Acta Historiae Artium Hungariae, 35: 115-167.

Wardzyński, M., 2009. The Great Competitors: the import and use of "red" marble from Hungary, Adnet, Stara Lubowla, Upper Hungary and Transylvania in small architecture and sculpture in the Commonwealth from the fourteenth century to the first half of the seventeenth century. Actes du XVle Colloque International de Glyptographie de Münsterschwartzach. Centre International de Recherches Glyptographiques: 333-388.

Wardzyński, M., 2015. The import and use of "red" marble in small architecture and sculpture in the Commonwealth from the fourteenth century to the first half of the seventeenth century (in Polish). www.fundacja-hereditas.pl/portal/files/czerwony_marmur_w_RP.pdf

apsida, www.apsida.sk

fara-kezmarok, www.fara-kezmarok.sk

hradlietava, www.hradlietava.sk

hradlubovna, www.hradlubovna.sk

chramsvjakuba, www.chramsvjakuba.sk 2015

kezmarok, www.kezmarok.sk

mapire.eu

mapserver, mapserver.geology.sk/gm50js

obnova, www.obnova.sk

rkcpoprad, www.rkcpoprad.sk

spiskastaraves, www.spisskastaraves.sk 